where the background is the same for both lines. The table actually gives values of $\log n$ for values of $\log (n+1) \mathrm{as}$, from the above, $(\delta-\gamma)_{T}=\log I_{T} / I_{B}$ and $\delta_{T}=\log \left(I_{T}+I_{B}\right) / I_{B}=\log \left(I_{T} / I_{B}+1\right)$.

If relative intensity values are obtained at a constant density from blackening curves ${ }^{2}$, as in the accompanying diagram, then $\delta T$ and $\delta S$ can be read off directly as shown, $(\delta-\gamma) T$ and $(\delta-\gamma)_{S}$ obtained from the table, whence $\log \left(I_{T} / I_{S}\right)$ follows by simple subtraction. If the lines are on backgrounds of differing intensity, the separations to the respective background curves are read, and to the difference of the $(\delta-\gamma)$ values is added the separation between the backgrounds, this being positive when the background of the trace element line is the stronger.

Where $\log \left(I_{T}+I_{B}\right), \log \left(I_{S}+I_{B}\right)$ and $\log I_{B}$ are obtained by single-value measurements, the $\delta$ values can be found by subtraction, otherwise the calculation follows the same lines. The table is thus of general application for the calculation of $\log a / b$ knowing $\log (a+x)$, log $(b+x)$ and $\log x$.

A suitable three-figure table of $(\delta-\gamma)$ for values of $\delta$, where $\gamma$ is the subtraction logarithm of $\delta$, of adequate accuracy for spectrographic analysis, has appeared in the Macaulay Institute Annual Report (1943-44) and offprints are available.

R. L. Mrtohell.

R. O. ScotT.

V. C. Farmer.

Macaulay Institute for Soil Research, Craigiebuckler,

Aberdeen.

Sept. 13.

1 Macaulay Institute Annual Report 1942-43.

scott, R. O., J. Soc. Chem. Ind., 68, 4 (1944).

\section{Vernalization of Rice}

IN certain parts of Bengal considerable rice crop of 'aus' paddy* is damaged, due to the incidence of early flood (July and August) submerging the whole crop when it is about to ripen. So it was considered that 'aus' plants might be made to escape the flood by reducing their life-period by the technique of vernalization. It must be mentioned that among the numerous varieties of 'aus' paddy there is no variety the life-period of which is less than ninety days, and these are usually low yielding. Hence an approach to the problem was made by reducing the life-period to less than ninety days of the existing high-yielding strains by vernalization.

Hedayetullah and Sen ${ }^{1}$ working on vernalization of 'aus' paddy have reported that this paddy responds to the treatment of vernalization, and the beneficial effects have been observed at higher temperatures. Flowering was significantly earlier than the control by vernalizing seeds at $29 \cdot 5^{\circ} \mathrm{C}$. for 15 and 10 days and $11^{\circ} \mathrm{O}$. for 15 days, the acceleration being $12 \cdot 06$, $7 \cdot 43$ and $4 \cdot 71$ days respectively. The yield of grains was reduced at $0^{\circ} \mathrm{C}$. and $11^{\circ} \mathrm{C}$., while at $29.5^{\circ} \mathrm{C}$. for both 15 and 10 days yield tended towards improvement.

The work was repeated with different temperatures $-5^{\circ}, 15^{\circ}$ and $35^{\circ} \mathrm{C}$. for 15 and 25 days with two 'aus' varieties, 'Thoranga' and 'Dhairal', early and late respectively, together with a control set for each variety in an attempt to account for the earliness of flowering of 'aus' varieties of rice at higher tempera-

* 'Aus' paddy is the summer paddy sown broadcast on the highlands in April-May and harvested in August-September.
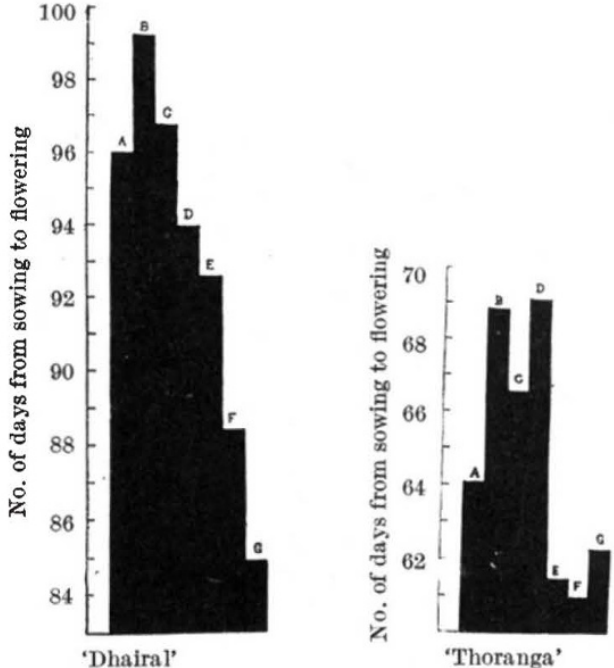

Histograms SHOWING THE RANGE OF FLOWERING OF 'DHALRAL' AND 'THORANGA'. FLOWERING IS MOST EARLY IN $G$ IN 'DHAIRAL', BUT THERE IS NO A PPRECYABLE RESPONSE TO HIGHER TEMPERATURES IN 'THORANGA'. FLOWERING IS RETARDED IN BOTH VARIETIES AT LOW TEMPERATURE.

$A$, control ; $B, 5^{\circ} \mathrm{C} ., 15$ days ; $C, 5^{\circ} \mathrm{C} ., 25$ days ; $D, 15^{\circ} \mathrm{C}$., 15 days ; $E, 15^{\circ} \mathrm{C}$., 25 days ; $F, 35^{\circ}$ C., 15 days; $G, 35^{\circ} \mathrm{C}$., 25 days.

tures. Here the induced earliness of flowering has been observed at $35^{\circ} \mathrm{C}$. for 15 and 25 days, the acceleration being $7 \cdot 5$ and $11 \cdot 2$ days respectively in 'Dhairal', while in 'Thoranga' no appreciable response has been obtained to any treatment of vernalization, as shown in the accompanying figure. It seems that vernalization has had very little effect on the early 'aus' variety. Flowering is retarded in both the varieties of rice at $5^{\circ} \mathrm{C}$. for 15 and 25 days and at $15^{\circ} \mathrm{C}$. for 15 days. In 'Dhairal', yield of grains per plant at $35^{\circ} \mathrm{C}$. for 15 and 25 days shows some improverment. So far, the experiment was conducted in pots. This year the vernalized seeds of 'aus' paddy are being tested on a randomized field scale against control (non-vernalized) seeds.

Full details of the experiments will be published elsewhere.

S. Hedayetullah.

B. N. Gновн.

Central Agricultural Research Station, Dacca, Bengal. July 4.

${ }^{1}$ Hedayetullah, S., and Sen, N. K., Sci. and Culture, 6, No. 11 (1941).

\section{Secretion of Pepsin in Achlorhydric Human Subjects after Injection of Histamine}

BABKIN $^{1}$ found in the gastric juice of dogs formed after the parenteral administration of histamine high acidity but little or no pepsin. Similarly, the histological preparations of Bowie and Vinberg ${ }^{2}$ showed the peptic cells affected after vagus stimulation but not after histamine. The findings in man are more contradictory. Bloomfield ${ }^{3}$ and Polland ${ }^{4}$ reported high concentration of pepsin in human stomach juice after histamine injection, but their data were not confirmed by Toby. Indeed it has been suggested that in the positive experiments enzyme which was secreted prior to the histamine injection was washed from the lumen of the tubules by the acid coming from the parietal (acid) cells ${ }^{5}$. 